\title{
Subglacial controls on the flow of Institute Ice Stream, West Antarctica
}

\author{
Martin J. SIEGERT, ${ }^{1}$ Neil ROSS, ${ }^{2}$ Jilu LI, ${ }^{3}$ Dustin M. SCHROEDER, ${ }^{4}$ David RIPPIN, ${ }^{5}$ \\ David ASHMORE, ${ }^{6}$ Robert BINGHAM, ${ }^{7}$ Prasad GOGINENI ${ }^{3}$ \\ ${ }^{1}$ Grantham Institute and Department of Earth Science and Engineering, Imperial College London, South Kensington, \\ London, UK \\ E-mail: m.siegert@imperial.ac.uk \\ ${ }^{2}$ School of Geography, Politics and Sociology, Newcastle University, Claremont Road, Newcastle Upon Tyne, UK \\ ${ }^{3}$ Center for the Remote Sensing of Ice Sheets, University of Kansas, Lawrence, KS, USA \\ ${ }^{4}$ Department of Geophysics, Stanford University, Stanford, CA, USA \\ ${ }^{5}$ Environment Department, University of York, York, UK \\ ${ }^{6}$ Centre for Glaciology, Aberystwyth University, Aberystwyth, UK \\ ${ }^{7}$ School of GeoSciences, University of Edinburgh, Edinburgh, UK
}

\begin{abstract}
The Institute Ice Stream (IIS) rests on a reverse-sloping bed, extending $>150 \mathrm{~km}$ upstream into the $\sim 1.8 \mathrm{~km}$ deep Robin Subglacial Basin, placing it at the threshold of marine ice-sheet instability. Understanding IIS vulnerability has focused on the effect of grounding-line melting, which is forecast to increase significantly this century. Changes to ice-flow dynamics are also important to IIS stability, yet little is known about them. Here we reveal that the trunk of the IIS occurs downstream of the intersection of three discrete subglacial features; a large 'active' subglacial lake, a newly-discovered sharp transition to a zone of weak basal sediments and a major tectonic rift. The border of IIS trunk flow is confined by the sediment on one side, and by a transition between basal melting and freezing at the border with the Bungenstock Ice Rise. By showing how basal sediment and water dictate present-day flow of IIS, we reveal that ice-sheet stability here is dependent on this unusual arrangement.
\end{abstract}

KEYWORDS: basal hydrology, ice dynamics, radio-echo sounding, sediments

\section{INTRODUCTION}

The West Antarctic Ice Sheet is thought vulnerable to 'marine ice-sheet instability', where grounding line recession accelerates over an increasingly deepening bed. Such instability can be forced by melting at the grounding line, as it is likely occurring across ice streams in the Amundsen Sea sector (Joughin and others, 2014; Rignot and others, 2014), and which may occur in the Weddell Sea sector later this Century (Hellmer and others, 2012). Ice-sheet modelling reveals the ice streams across the Weddell Sector, and in particular the Institute Ice Stream (IIS) and Möller Ice Stream (MIS) are highly sensitive to melting at their grounding lines (Wright and others, 2014). These two ice streams have a relatively flat surface profile upstream of the grounding line, comparable with those in the Siple Coast, which means the ice in their trunks is relatively close to flotation (Scambos and others, 2004; Ross and others, 2012) in contrast with Thwaites Glacier, for example. Knowledge of ice flow processes in the Weddell Sea sector, and in particular of ice stream trunk flow, is also critical to regional ice-sheet stability, as accelerated grounding line retreat could be triggered by ice flow reduction and the resulting net mass loss at the grounding line, through thinning-induced flotation if flow is increased, or de-buttressing associated with ice shelf thinning.

Buckled internal ice-sheet layers and surface stripes across the Bungenstock Ice Rise (BIR) testify to the region having undergone substantial change during the last few thousand years, and possibly as recently as a few centuries ago (Siegert and others, 2013). This is in contrast to tributaries feeding into the trunk of the IIS from the Ellsworth Mountains, which appear well constrained by subglacial topography and, hence, are likely to be relatively stable features (Ross and others, 2011, 2014). As the configuration of the IIS is likely to be newly established, it is important to understand the conditions and processes leading to IIS flow, as their robustness may dictate future regional ice-sheet change.

The location and cause of ice stream trunk flow have been ascribed to several different drivers (i.e. bed topography, subglacial geology, the subglacial transition from bedrock to deformable sediment and the presence of subglacial water) (Anandakrishnan and others, 1998; Bell and others, 1998; Siegert and Bamber, 2000; Langley and others, 2014). Here, we examine airborne radar sounding information, in conjunction with interferometric synthetic aperture radar (InSAR) measurements of ice-surface velocities (Rignot and others, 2011), to reveal which combination of these (and other) variables are associated with the trunk of the IIS.

\section{GEOPHYSICAL DATA AND ICE STREAM FLOW}

In the Austral summer of 2010/11 >25 $000 \mathrm{~km}$ of airborne geophysical profiles (radar sounding, gravity, magnetics and LIDAR) were collected by the British Antarctic Survey (BAS) across the trunks and upstream regions of the IIS and MIS, revealing their topographic (Ross and others, 2012) and geological (Jordan and others, 2013) settings, and the region's recent (Holocene) glacial history (Siegert and others, 2013). The BAS radar is a coherent system with a carrier frequency of $150 \mathrm{MHz}$, a bandwidth of $12 \mathrm{MHz}$ and 
a
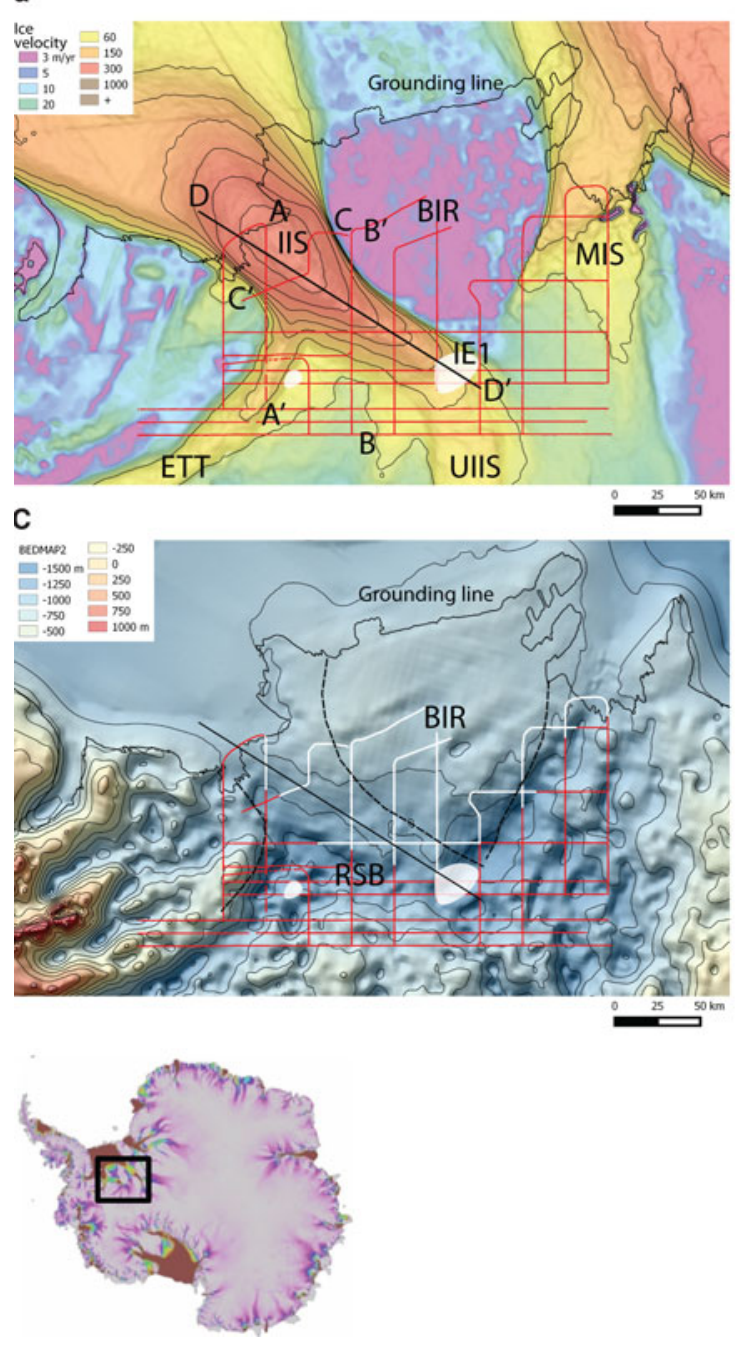

b
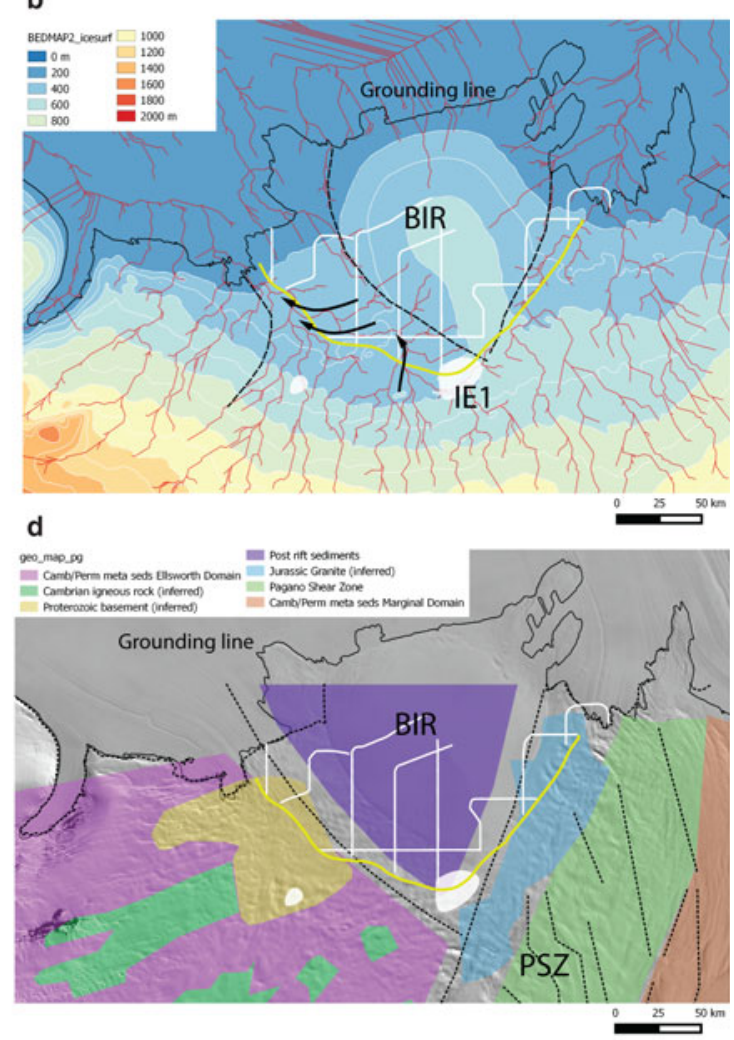

Fig. 1. Boundary conditions at the onset region, trunk and grounding line of the Institute Ice Stream. (a) Airborne radar profiles, annotated as in Figures 2, 3, superimposed over InSAR-derived ice-surface velocities (Rignot and others, 2011). (b) Direction of basal water flow (after Shreve, 1972) superimposed over ice-sheet surface elevation (Fretwell and others, 2013). Black arrows indicate the general flow direction of water. (c) Subglacial bed topography (Fretwell and others, 2013). (d) Crustal lithological structures and units (adapted from Jordan and others, 2013), superimposed on MODIS imagery. Note sinuous ice-sheet surface channels are seen at the grounding lines of IIS and MIS (after Le Brocq and others, 2013). In (b) and (d), yellow line denotes the boundary of a smooth, bright bed reflector from water-saturated subglacial sediments (as shown in Fig. 2), and grey shade denotes the position and extent of 'active subglacial lake' Institute E1 (Smith and others, 2009). IIS, MIS, BIR, ETT, UIIS, RSB, IE1 and PSZ refer to the Institute Ice Stream, Möller Ice Stream, Bungenstock Ice Rise, Ellsworth Trough Tributary, Upstream Institute Ice Stream, Robin Subglacial Basin, Institute E1 and Pagano Shear Zone, respectively. A location map is provided in the inset.

acquires waveforms at a rate of $312.5 \mathrm{~Hz}$. These data have been supplemented by those acquired by the Center for the Remote Sensing of Ice Sheets (CReSIS) during the Operation Ice Bridge (OIB) programme in 2012 and 2014. In 2012 a radar profile was acquired, using a system operating at a centre frequency of $195 \mathrm{MHz}$ and bandwidth of $10 \mathrm{MHz}$ (Rodriguez-Morales and others, 2013), along the main flow axis of the IIS. In 2014 an upgraded radar with a bandwidth of $50 \mathrm{MHz}$ was used to collect profiles upstream of the IIS grounding line.

Surface ice velocities, derived from satellite InSAR, allow the flow structure of the IIS, its tributaries and its margins, to be located and quantified (Fig. 1). The data reveal two unusual features about the flow of the IIS. First, the greatest ice velocities are not observed in the deepest regions of the Robin Subglacial Basin. Instead they occur over the northern half of the basin, adjacent to the BIR, making the northern shear margin particularly pronounced. Second, the trunk of the IIS (in which maximum velocities occur) is located downstream of the bifurcation of flow around the south-eastern edge of BIR (Fig. 1). These associations underline the importance of the development and stability of the BIR to the organisation of regional ice-sheet flow.

Airborne gravity and magnetic data reveal that the IIS onset occurs over the recently discovered Pagano Shear Zone (Jordan and others, 2013) (Fig. 1). The edge of the shear zone aligns with the downstream shear margins of the MIS, making the position of this ice stream strikingly tectonically-controlled and, therefore, likely adding to its spatial stability. The general flow direction of MIS is similar to that depicted in surface stripes across the BIR (Siegert and others, 2013), which further supports MIS flow-direction stability during recent (Late Holocene) regional ice-sheet change.

The trunk of IIS is also downstream of an 'active' subglacial lake, named Institute E1, which was detected by five 
pairs of repeat track ICESat ice-surface elevation measurements, revealing that the lake 'filled' by $\sim 0.5 \mathrm{~km}^{3}$ between October 2003 and March 2008 (Smith and others, 2009) (Fig. 1). Institute E1 is one of the largest (by area) of such 'active' lakes (Smith and others, 2009), although estimates of its volume are low, due to relatively small ice elevation changes observed over it. As in many other 'active' subglacial lakes radar data reveal a lack of evidence for the deep pooled water that is known to exist in lakes beneath the centre of the ice sheet, such as Lake Ellsworth (Siegert and others, 2004; Woodward and others, 2010). While the absence of evidence has led to a debate on the true nature of 'active' subglacial lakes (Wright and others, 2012, 2014; Siegert and others, 2014, 2016), including whether they should be referred to as 'lakes' at all, the surface elevation changes detected are likely to be due to subglacial water flow and, thus, they may be conduits and/or ephemeral stores of water between the upstream catchment and the ice stream. The association between Institute E1 and the trunk flow of IIS downstream points to a hydrological control on enhanced ice flow, similar to that reported at the heads of several other ice streams (Siegert and Bamber, 2000; Bell and others, 2007).

\section{SUBGLACIAL SEDIMENTS AND ICE FLOW}

Radar profiles reveal where weak porous sediments are likely to exist over the Robin Subglacial Basin, based on a morphologically ultra-smooth bed that has a high level of radar-reflectivity (Fig. 2; Rippin and others, 2014), similar to the bed of the Siple Coast where basal sediments have been collected (Engelhardt and others, 1990; Bentley and others, 1998; Peters and others, 2005). The spatial distribution of basal sediment is extremely well defined, as there is a noticeably sharp border between the smooth and rough beds in the radar data. The sediment is concentrated across the northern half of the Robin Subglacial Basin, and extends along the trough axis between the IIS grounding line and onset (Fig. 1).

Radar data also reveal the bed of the BIR to be similarly smooth, hence the IIS shear zone separating the ice stream and ice rise cuts across the basal sediment field (Fig. 2). The shear zone is characterised by a marked transition in bed reflectivity, from low reflected power beneath the ice rise to high reflected power (Fig. 2). Given that ice thickness change across the shear zone is relatively small, the bed reflectivity change must be due to the contrast between frozen and wet basal conditions. Although attenuation contrasts between these ice bodies might conceivably also account for a difference in basal reflectivity, radar attenuation in the ice stream is likely stronger than on the nearby ice rise (Matsuoka and others, 2012), which means the actual contrast is likely to be greater than we measure. Through these data it is reasonable to assume that the basal sediments beneath the ice stream are wet, and the hydrological processes within the sediments, governing their strength, must be affected by the lateral transition zone (i.e. water does not flow across the shear margin).

The radar data also show the deepest regions of the Robin Subglacial Basin are much rougher than and $250 \mathrm{~m}$ below, the smooth planar surface of the adjacent region of basal sediments (Fig. 2). Hence the deepest part of the Robin Subglacial Basin coincides neither with basal sediments nor the highest ice velocities.
The wider IIS is divided into two main tributaries; the Ellsworth Trough tributary and the upstream IIS. The former supplies ice into the deepest regions of the Robin Subglacial Basin, whereas ice over the sediment plain originates predominantly from the upstream IIS. Ross and others (2012) demonstrate how the Ellsworth Trough tributary is likely to be stable and ancient, due to its strong topographical control. This may explain why the bed across the deepest regions of the trough is rough, due to either glacial excavation of sediment or lack of deposition.

Water is certainly thought to run through the deepest part of the Robin Basin, as demonstrated by hydrological flowpaths, calculated from the hydropotential surface (Shreve, 1972), that terminate at the margin where evidence for subglacial plumes exiting the ice sheet has been found (Le Brocq and others, 2013) (Fig. 1). One explanation for this arrangement is that the subglacial drainage network is well organised, leading to low basal water pressures and, therefore, high effective pressures. This is in contrast to the region in which sediments exist, as water flow paths meander in a manner consistent with a highly distributed hydrological system. Such an arrangement is compatible with high pore-water pressures leading to very weak dilated sediment.

It seems likely that Institute E1 feeds water, albeit intermittently, to the sedimentary bed of the ice stream. Hydrological flow paths show how water flows into the sediment upstream of the IIS trunk, and then leaves the sediment field to flow into the deep axis of the Robin Subglacial Basin prior to exiting the ice sheet as a well-define channel at the grounding line (Le Brocq and others, 2013) (Fig. 1). It is currently not known whether the sediment water budget is balanced, or whether water is being held within, or taken from, the sediment. As postulated by Christoffersen and others (2014), this water balance is likely to be critical to the stability of sedimentary properties.

\section{FLOW-AXIS BED MORPHOLOGY}

Airborne radar data acquired by OIB along the approximate flow axis of the IIS, confirms the grounding line sits atop of a reverse slope (DD' in Figs 1, 3) as proposed with more limited data by Ross and others (2012). It also reveals that a small $(\sim 100 \mathrm{~m})$ bump in the overall bed slope exists immediately upstream of the grounding line, which could act as a local stabilising influence to retreat. Not all of the more recent CReSIS transects show this bump, however, suggesting that it does not extend across the full width of the grounding line.

Further upstream the bed undulates slightly as it deepens. The largest topographic features in the OIB data are two fairly abrupt reverse sloping steps; one half way between Institute E1 and the grounding line, across which the bed falls by $\sim 200 \mathrm{~m}$ in $\sim 7 \mathrm{~km}$, and a second steeper step that drops down to Institute E1 by 400-500 m over 10 km (Fig. 3). These bed-elevation steps coincide with surface crevassing observed in Radarsat imagery, formed as a consequence of ice flow over the subglacial obstacles, suggesting that they are laterally-extensive features.

Radar profile DD' (Fig. 3) provides further information about the nature of ice/bed interface. First, the bed is generally smooth and flat across $>100 \mathrm{~km}$ consistent with the presence of basal sediments identified earlier. Second, between the grounding line and the first bed step, numerous small reflection hyperbolas are observed at the bed. These are 


\section{Profile A-A'}

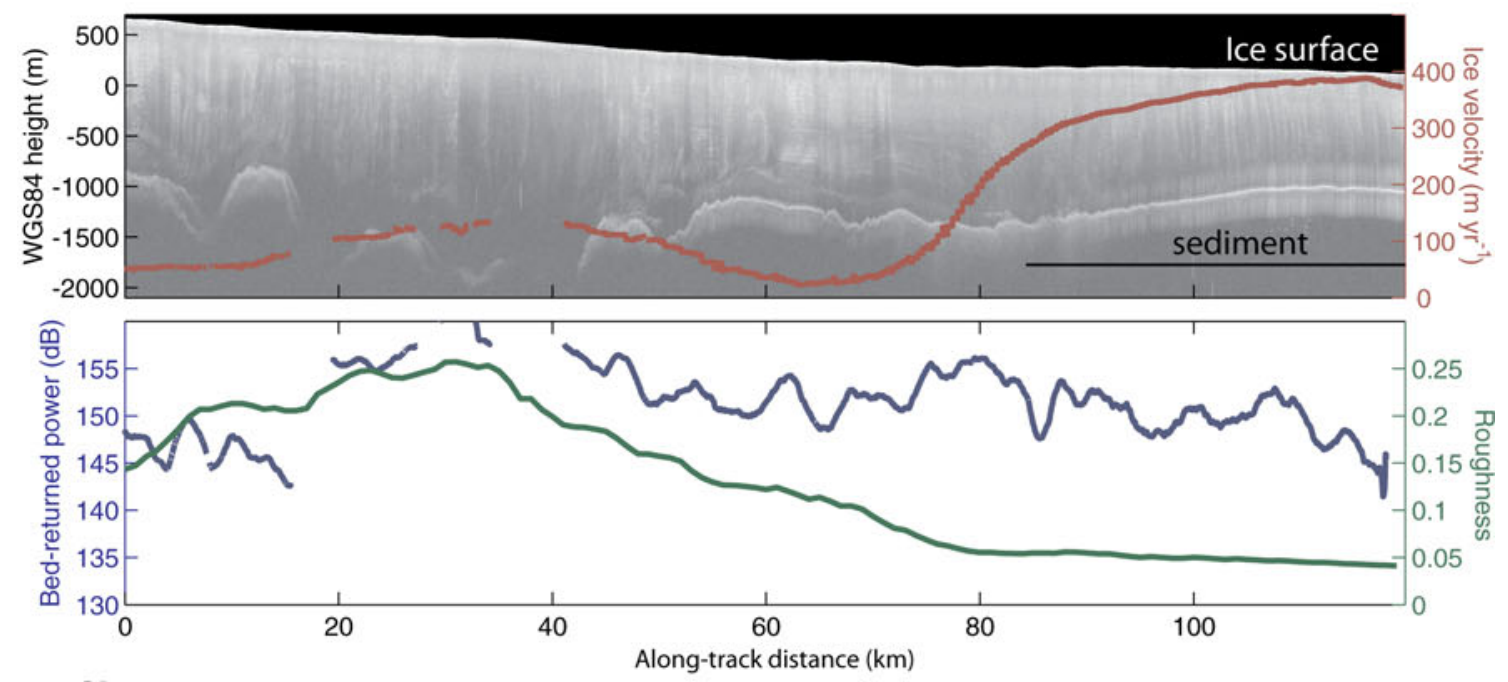

\section{Profile B-B'}
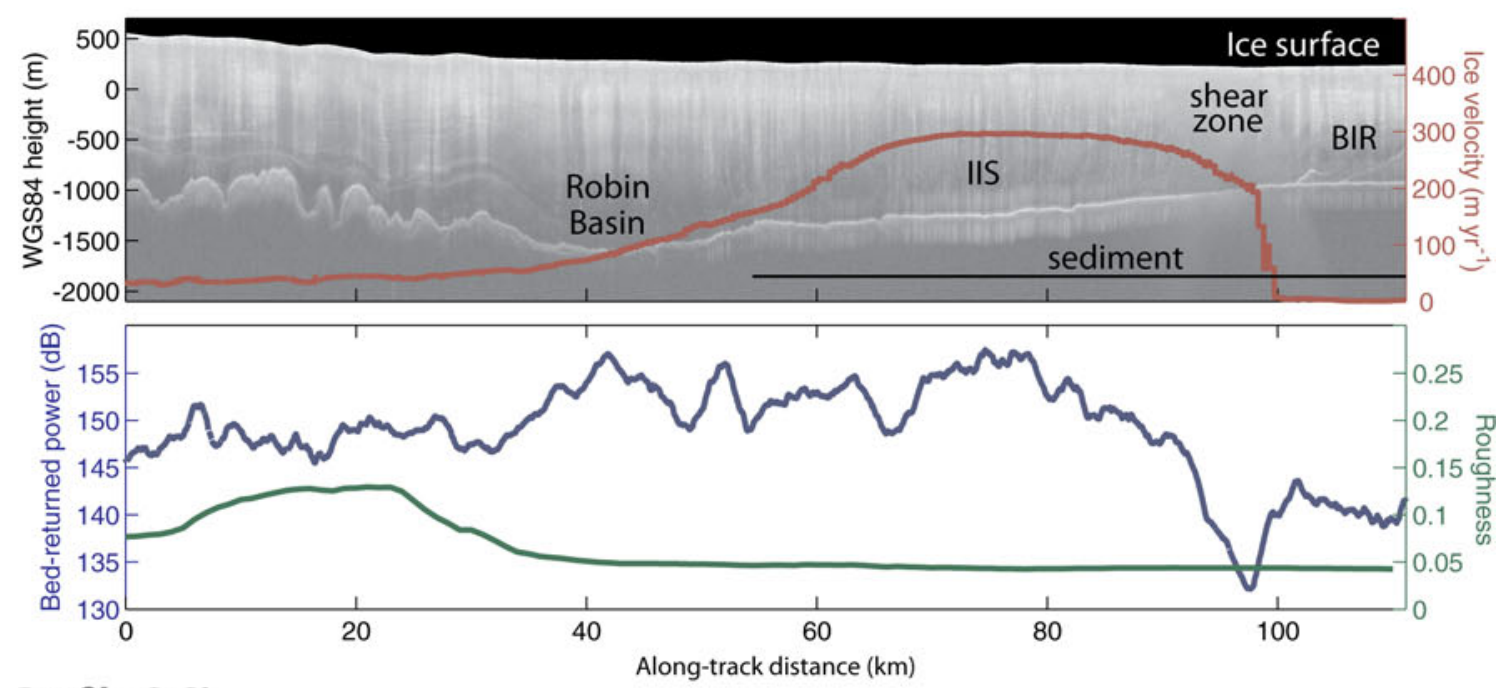

\section{Profile C-C'}
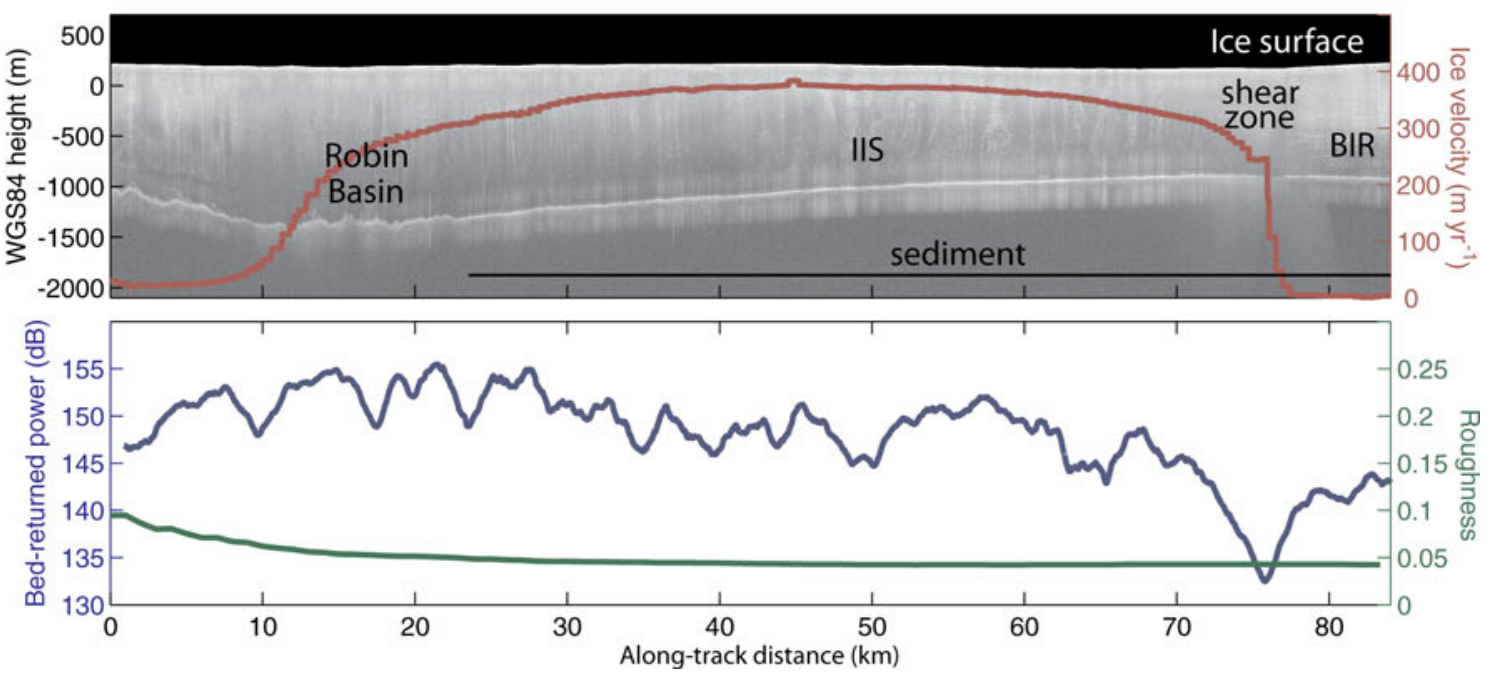

Fig. 2. Radar sounding profiles acquired by the British Antarctic Survey in 2010/11, revealing the flat interface indicative of water-saturated basal sediment. Locations for each profile are annotated in Figure 1. (a) $\mathrm{AA}^{\prime}$. (b) BB'. (c) $C C^{\prime}$. IIS and BIR refer to the Institute Ice Stream and Bungenstock Ice Rise, respectively. Ice-surface velocities (after Rignot and others, 2011) are provided (red) with bed reflectivities (blue) and basal roughness (green) along each profile. Note in all profiles the association between the greatest ice velocities within the IIS and the region of the bed interpreted as comprising water-saturated basal sediments. Note also in BB' and $\mathrm{CC}^{\prime}$ the association between the marked change in ice-surface velocity across the IIS shear margin and bed reflection strength, due a sharp transition between wet (IIS) and frozen (BIR) basal sediments. 


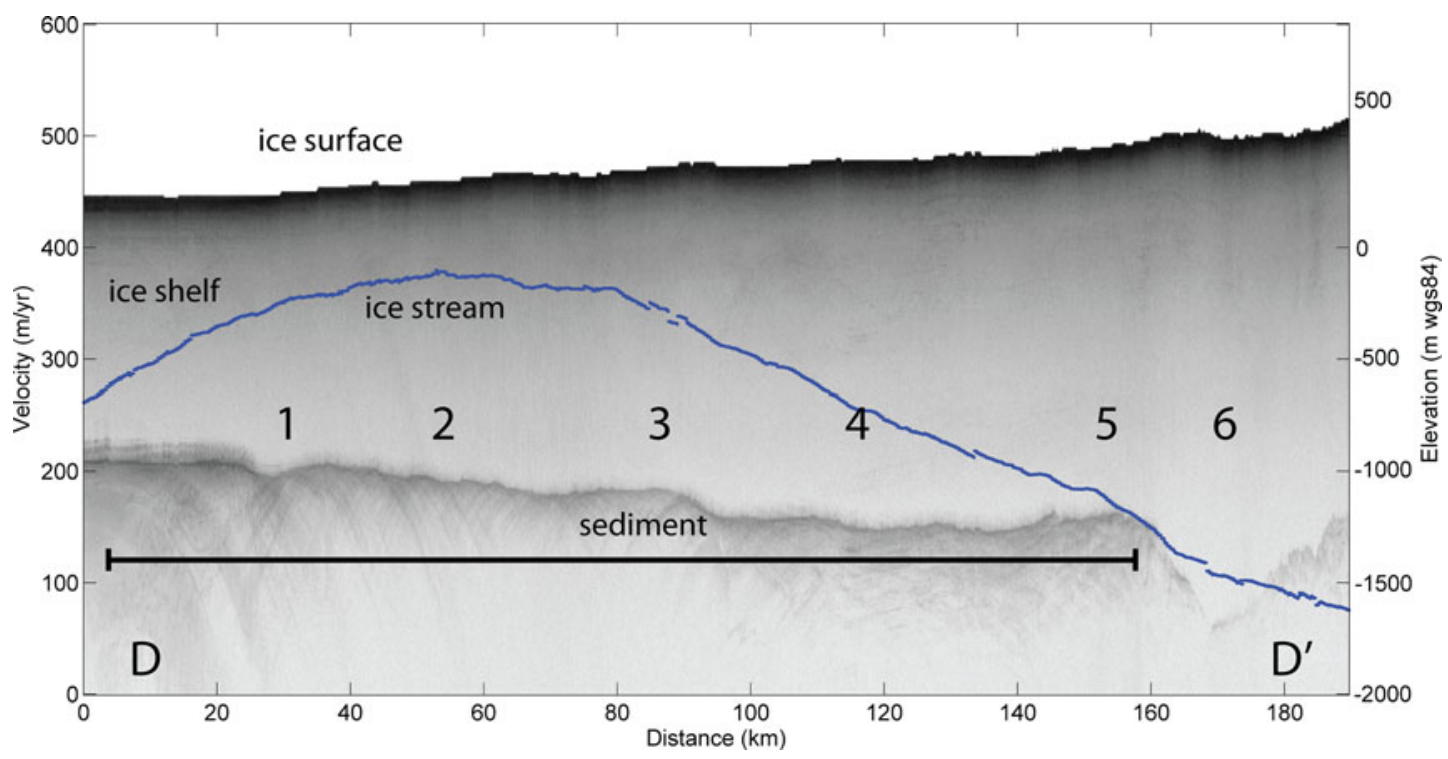

Fig. 3. A radar profile along the central flow axis of the IIS, acquired by Operation Ice Bridge in 2012. The location of the profile, DD', is provided in Figure 1. Labels on the radargram denote the following characteristics. (1) The ice-stream grounding line and a small normal sloping bed slope. (2) Smooth, reverse-sloping ice stream bed. (3) A steep reverse-sloping topographic step, in which the bed elevation decreases by $\sim 200 \mathrm{~m}$ over $\sim 7 \mathrm{~km}$. (4) Flat, reverse-sloping ice stream bed. (5) A second steep reverse-sloping step, where the bed elevation lowers by $400-500 \mathrm{~m}$ over $\sim 10 \mathrm{~km}$. (6) The location of Institute E1. Notice there is little evidence in the radar profile for deep pooled water, of the type characteristic of subglacial lakes in both East and West Antarctica (Wright and others, 2012, 2014; Siegert and others, 2014). Also shown along the profile is the ice-surface velocity (after Rignot and others, 2011).

processing artefacts that were removed using the upgraded radar system in 2014 and are, therefore, not directly diagnostic of bed roughness properties. Indeed the 2014 fully processed data confirm the bed is remarkably smooth in this region (see Supplementary Information).

\section{SUMMARY AND DISCUSSION}

While geophysical data indicate the trunk of IIS is associated with a combination of topography, sedimentology, geology and hydrology, of these controls the only parameter likely to vary substantially over a short timescale is hydrology. Institute E1 is located at a hydrological focus for the majority of the upper IIS catchment (except that issued via the Ellsworth Trough). As the flow of basal water is heavily dependent on ice-surface slope (being around ten times more influential than basal topography) (Wright and others, 2008), even small changes to the icesheet configuration are likely to lead to deviation in the flow of water into and out of Institute E1. In this way, hydrological changes associated with Institute E1, and its upstream supply, may lead to changes in the flow of water to basal sediments downstream. Such change could result in to modification to till strength and, potentially, migration of the frozen-wet shear margin that borders the BIR. A similar situation has been observed across the shear margin of Thwaites Glacier in West Antarctica (MacGregor and others, 2013; Schroeder and others, in review). The persistent supply of water to the IIS sediments is thus crucial to ice stream stability, adding further to the idea that IIS is at a physical threshold of change (Ross and others, 2012).

Such hydrological change is likely to have occurred as a result of Late Holocene ice-sheet reconfiguration (Siegert and others, 2013), as exemplified by surface stripes across the BIR, suggesting broad ice flow in a direction similar to the MIS as recently as a few centuries ago.

Cryosat2 radar altimetry of the IIS catchment indicates ice surface lowering between 2010 and 2013 (Helm and others, 2014; McMillan and others, 2014), on the order of (albeit less than) that upstream of Pine Island and Thwaites Glaciers, where major ice loss at the grounding line has also been observed. While the explanation for lowering in the Weddell Sea Sector is not known, ice-sheet thinning is as plausible an explanation as surface mass-balance variability. If this is an ice-dynamic signal, there are two ways of explaining it. First, the region continues to thin through its post last glacial maximum relaxation. Second, recently enhanced ice flow has led to dynamic thinning. Both could lead to adjustments in ice-surface slope and, thus, the routing of basal water flow, which may influence ice dynamics through alteration to the strength of basal sediments.

The IIS, shown previously to be at a physical threshold of ice-sheet change (Ross and others, 2012) may be vulnerable as a consequence of a rare combination of subglacial conditions and processes prone to alteration under little forcing.

\section{SUPPLEMENTARY MATERIAL}

The supplementary material for this article can be found at http://dx.doi.org/10.1017/aog.2016.17.

\section{ACKNOWLEDGEMENTS}

Data used for this article are available at the UK Airborne Geophysics Data Portal https://secure.antarctica.ac.uk/data/ aerogeo/ and at the Center for the Remote Sensing of Ice Sheets data portal https://data.cresis.ku.edu/. Funding for CReSIS data collection and development of radars is provided by NASA and NSF. M. J. S. and N. R. acknowledge 
funding by NERC Antarctic Funding Initiative (Ref. NE/ G013071/1). Part of the research was carried out at the Jet Propulsion Laboratory, California Institute of Technology, under a contract with the National Aeronautics and Space Administration.

\section{REFERENCES}

Anandakrishnan S, Blankenship DD, Alley RB and Stoffa PL (1998) Influence of subglacial geology on the position of a West Antarctic ice stream from seismic observations. Nature, 394, $62-65$

Bell RE and 6 others (1998) Influence of subglacial geology on the onset of a West Antarctic ice stream from aerogeophysical observations. Nature, 394, 58-62

Bell RE, Studinger M, Shuman CA, Fahnestock MA and Joughin I (2007) Large subglacial lakes in East Antarctica at the onset of fast-flowing ice streams. Nature, 445, 904-907

Bentley CR, Lord N and Liu C (1998) Radar reflections reveal a wet bed beneath stagnant Ice Stream $C$ and a frozen bed beneath Ridge BC, West Antarctica. J. Glaciol., 44, 149-156

Christoffersen $\mathrm{P}$, Bougamont $\mathrm{M}$, Carter SP, Fricker HA and Tulaczyk S (2014) Significant groundwater contribution to Antarctic ice streams hydrologic budget. Geophys. Res. Lett., 41 (doi: 10.1002/2014GL059250)

Engelhardt H, Humphrey N, Kamb B and Fahnestock M (1990) Physical conditions at the base of a fast moving Antarctic ice stream. Science, 248, 57-59 (doi: 10.1126/science.248.4951.57)

Fretwell P and 59 others (2013) Bedmap2: improved ice bed, surface and thickness datasets for Antarctica. Cryosphere, 7, 375-393

Hellmer HH, Kauker F, Timmermann R, Determann J and Rae J (2012) Twenty-first-century warming of a large Antarctic ice-shelf cavity by a redirected coastal current. Nature, 485, 225-228

Helm V, Humbert A and Miller H (2014) Elevation and elevation change of Greenland and Antarctica derivd from Cryosat-2. Cryosphere, 8, 1539-1559 (doi: 10.5194/tc-8-1539-2014)

Jordan TA and 8 others (2013) Inland extent of the Weddell Sea Rift imaged by new aerogeophysical data. Tectonophysics, 585, 137-160 (doi: 10.1016/j.tecto.2012.09.010)

Joughin I, Smith BE and Medley B (2014) Marine ice sheet collapse potentially under way for the Thwaites Glacier Basin, West Antarctica. Science, 344, 735-738 (doi: 10.1126/science.1249055)

Langley $\mathrm{K}$ and 5 others (2014) Onset of fast ice flow in recovery ice stream, East Antarctica: a comparison of potential causes. J. Glaciol., 60, 1007-1014 (doi: 10.3189/2014JoG14J067)

Le Brocq A and 10 others (2013) Evidence from ice shelves for channelized meltwater flow beneath the Antarctic ice sheet. Nat. Geosci., 6, 945-948 (doi: 10.1038/ngeo1977)

MacGregor JA and 7 others (2013) Weak bed control of the eastern shear margin of Thwaites Glacier, West Antarctica. J. Glaciol., 59, 900-912 (doi: 10.3189/2013JoG13J050)

Matsuoka K, MacGregor JA and Pattyn F (2012) Predicting radar attenuation within the Antarctic ice sheet. Earth Planet. Sci. Lett., 359-360, 173-183 (doi: 10.1016/j.epsl.2012.10.018)

McMillan M and 7 others (2014) Increased ice losses from Antarctica detected by CryoSat-2. Geophys. Res. Lett., 41, 3899-3905 (doi: 10.1002/2014GL060111)

Peters M, Blankenship D and Morse D (2005) Analysis techniques for coherent airborne radar sounding: application to West Antarctic ice streams. J. Geophys. Res., 110, B06303 (doi: 10.1029/2004JB003222)
RignotE, Mouginot J and Scheuchl B (2011) Ice flow of the Antarctic ice sheet. Science, 333, 1427-1430 (doi: 10.1126/science.1208336)

Rignot E, Mouginot J, Morlighem M, Seroussi H and Scheuchl B (2014) Widespread, rapid grounding line retreat of Pine Island, Thwaites, Smith, and Kohler glaciers, West Antarctica, from 1992 to 2011. Geophys. Res. Lett., 41, 3502-3509 (doi: 10.1002/2014GL060140)

Rippin DM and 9 others (2014) Basal roughness of the Institute and Möller ice streams: process determination and landscape interpretation. Geomorphology, 214, 139-147

Rodriguez-Morales F and 17 others (2014) An advanced multifrequency radar instrumentation suite for polar research. IEEE Trans. Geosci. Remote Sens., 52(5)

Ross $\mathrm{N}$ and 8 others (2011) Holocene stability of the AmundsenWeddell Sea ice divide, West Antarctica. Geology, 39, 935938 (doi: 10.1130/G31920.1)

Ross N and 9 others (2012) Steep reverse bed slope at the grounding line of the Weddell Sea sector in West Antarctica. Nat. Geosci., 5, 393-396 (doi: 10.1038/ngeo1468)

Ross N and 8 others (2014) The Ellsworth Subglacial Highlands: inception and retreat of the West Antarctic ice sheet. Geol. Soci. Am. Bull., 126, 3-15 (doi: 10.1130/B30794.1)

Scambos T, Bohlander J, Raup B and Haran T (2004) Glaciological characteristics of Institute ice stream using remote sensing. Antarct. Sci., 16, 205-213 (doi: 10.1017/S0954102004001919)

Shreve RL (1972) Movement of water in glaciers. J. Glaciol., 11, 205-214

Siegert MJ and Bamber JL (2000) Subglacial water at the heads of Antarctic ice-stream tributaries. J. Glaciol., 46, 702-703

Siegert MJ and 7 others (2004) Subglacial Lake Ellsworth: a candidate for in situ exploration in West Antarctica. Geophys. Res. Lett., 31, L23403 (doi: 10.1029/2004GL021477)

Siegert MJ, Ross N, Corr H, Kingslake J and Hindmarsh R (2013) Late Holocene ice-flow reconfiguration in the Weddell Sea sector of West Antarctica. Quat. Sci. Rev., 78, 98-107 (doi: 10.1016/j. quascirev.2013.08.003)

Siegert MJ and 8 others (2014) Boundary conditions of an active West Antarctic subglacial lake: implications for storage of water beneath the ice sheet. Cryosphere, 8, 15-24 (doi: 10.5194/tc-8-15-2014)

Siegert MJ, Ross N and Le Brocq A (2016) Recent advances in understanding Antarctic subglacial lakes and hydrology. Philos. Trans. R. Soc. London A, 374, 20140306. http://dx.doi.org/10. 1098/rsta.2014.0306

Smith BE, Fricker HA, Joughin IR and Tulaczyk S (2009) An inventory of active subglacial lakes in Antarctica detected by ICESat (2003-2008). J. Glaciol., 55, 573-595

Woodward J and 9 others (2010) Location for direct access to subglacial Lake Ellsworth: an assessment of geophysical data and modelling. Geophys. Res. Lett., 37, L11501 (doi: 10.1029/ 2010GL042884)

Wright AP, Siegert MJ, Le Brocq A and Gore D (2008) High sensitivity of subglacial hydrological pathways in Antarctica to small ice sheet changes. Geophys. Res. Lett., 35, L17504 (doi: 10.1029/ 2008GL034937)

Wright AP and 12 others (2012) Evidence of a hydrological connection between the ice divide and ice sheet margin in the Aurora Subglacial Basin, East Antarctica. J. Geophys. Res., 117 (doi: 10.1029/2011JF002066)

Wright AP and 10 others (2014) Sensitivity of the Weddell Sea sector ice streams to sub-shelf melting and surface accumulation. Cryosphere, 8, 2119-2134 (doi: 10.5194/tc-8-2119-2014) 